\title{
A historic humanitarian collaboration in the Pacific context
}

\author{
Robert Bradley Mitchell ${ }^{a}$, Nathan John Grills ${ }^{b}$
}

\author{
a PhD, CEO, Anglican Overseas Aid, Australia \\ ${ }^{b}$ MBBS, MPH, DPhil, Nossal Institute of Global Health, University of Melbourne, Australia
}

The purpose of this article is to report on a historic collaboration between Australian faithbased development agencies and their partners in the Pacific. The collaboration is called the Church Agencies Network Disaster Operations (CAN DO), comprising a group of eight Australian church-based development organisations, each comprising established relationships with counterpart churches in the Pacific. The formal collaboration began in mid-2016, and program activity between members is in its infancy.

The context for CAN DO was the recognition that climate change was damaging health and wellbeing in Pacific communities - especially in terms of climate-related disasters - and that churches had a unique role within the civil society in the region. Specifically, CAN DO participants had recognised that more could be achieved by acting together than alone and by moving beyond traditional "siloed" denominational relationships.

This case study aims to describe this unique inter-denominational collaboration and to explore the factors that have led to its formation.

\section{Vulnerability of Pacific to Climate \\ Change}

In its fourth assessment report, the Intergovernmental Panel on Climate Change (IPCC) identified the Pacific region, especially small island states, as being one of the most exposed areas in the world to the adverse implications of climate change. ${ }^{1}$ For several low-lying coral island states, climate change represented an existential threat, and the prospect of climate-induced migration was in view. ${ }^{2}$ For other parts of the Pacific, the impact was felt in lost revenue from agriculture, the strain on water resources, and degradation of infrastructure through disasters.

Evidence from the fifth IPCC assessment reports growing evidence of the link between global warming and the frequency, intensity, and spatial extent of extreme weather events. ${ }^{3}$ In the Pacific, this is experienced not only as tropical cyclones and typhoons, but also as periods of prolonged drought due to changes in weather patterns. For example, Cyclone Pam, in Vanuatu in 2015, was immediately followed by a period of drought, which defeated attempts to replant damaged crops and compounded risks to food security.

In terms of health impacts, the WHO (World Health Organisation) has comprehensively assessed climate-sensitive health risks in the Pacific. Risks identified include trauma from extreme weather events, heat-related illnesses, compromised safety and security of water and food, and vector-borne diseases. ${ }^{4}$ Comparatively, Pacific island countries are among the most vulnerable societies in the world to the health impacts of a changing climate. ${ }^{5}$ The remote nature of Pacific Island communities and the limited resources available to their governments for adaptation and prevention are exacerbating the risks. Against this background, civil society organisations have an added responsibility.

\section{The Role of Churches within Pacific}

\section{Societies}

\section{Historical context}

To understand the dominant role of churches in Pacific societies, it is necessary to reflect briefly on their colonial history. In most other colonial contexts, the interface with the rest of the world 
came primarily as the result of securing economic or other national interests of the colonial power. The Pacific, in general, presented fewer opportunities. It was seen as a high-cost and relatively inaccessible context with fewer natural resources suitable for exploitation. In addition, it was distant from the military or strategic concerns of many European powers. For this reason, the Pacific was conceptualised by colonialists more as a mission field than as a place to secure other types of interests.

The Oxford Handbook of Global Religions summarised, "When one considers processes of globalisation in the Pacific islands, one is struck by the extent to which religion has been central to them. There are grounds to argue that religion, and Christianity in particular, has been the single most powerful globalising force. . " ${ }^{6}$ Churches were central to that engagement, pursuing their missionary and social goals by inculcating outposts of "civilisation" (as they saw it) right across the region. Initiatives associated with missionary endeavour were also the precursors to many modern development programs, although recognition for this has been somewhat belated. Clarke blames their invisibility on the development sector itself in failing to recognise the importance of religion within its largely secular worldview. ${ }^{7}$ Even after independence, many educational, social, and welfare facilities have continued to be run by the churches. ${ }^{7}$ Relevantly for CAN DO, the international denominational linkages have endured through formal association with corresponding indigenous churches.

\section{Present day}

Christianity remains the dominant religion across the region and most people claim a specific Christian faith. ${ }^{8}$ There are high levels of church attendance, and the place of religion is integrated into the functioning of many aspects of the society. Religious belief is not held separately from other domains of life such as economics or politics. ${ }^{6}$ In many Pacific countries, church-based institutions engender more trust and reliance for ordering interpersonal and societal relationships than does the state. ${ }^{8}$ The churches have high levels of legitimacy and public support, and claim a moral authority that has largely diminished in the West. ${ }^{9}$ In the Pacific, Christianity has been singled out as constituting "the one set of ideas that is both widely shared and highly valued by the majority of citizens of each state," making it a natural focus for nation-building efforts. ${ }^{6}$

The statistics bear out the dominance of Christianity in the region. The most populous part of the Pacific is the subregion of Melanesia (which includes the nations of Papua New Guinea, Solomon Islands, and Vanuatu). Melanesia identifies as $90 \%$ Christian, with some areas as high as $95 \% .{ }^{10}$ It has been reported that when the settler nations of Hawaii and New Zealand are excluded, the rest of the Pacific islands are 99\% Christian. ${ }^{6}$ There are elements of nominalism and syncretism in many communities, but Christianity and its institutions continue to have a profound social resonance.

\section{Geography and Government}

\section{Capacity}

While a significant role fell to the churches under colonial administrations, it is also important to understand the ongoing influence of the region's geography. Power structures tend to be more localised than centralised because of remoteness. Nations like Vanuatu, Solomon Islands, and Tonga are spread across large island groups and archipelagos, many of which are uninhabited. Some islands are hundreds of kilometres from the capital, and may only be accessed infrequently by boat.

In places like Papua New Guinea (PNG), the mountainous and dense forest terrain creates remoteness of a different kind. The fact that there are over 800 indigenous languages in PNG indicates that many communities have developed in relative isolation from each other.

Against this background, the footprint of the central government has often been significantly reduced beyond the capital city. Historically, churches have helped to bridge the gap, carrying out activities like health care and education, which in other settings are often the responsibility of government. For example, Clarke notes, "There 
was an almost entire dereliction of duty by the dual-ruling French and English colonial powers within Vanuatu with direct involvement in the provision of health and education services not occurring until the mid-1960s." 10 (page 5) These activities were seen by the churches as consistent with their theological mandate for social care, and were usually a welcome adjunct to their physical presence.

\section{Recognition of Faith-based Actors}

The Australian government recognises that faith-based actors are well placed to contribute to development goals in the Pacific context. The Church Partnership Program (CPP), a part of its official aid program, commissioned a case study reviewing its progress. The report sets out succinctly some of the arguments supporting working through churches in PNG:

Working with the churches in PNG is highly relevant for the PNG context. With strong legitimacy among the population, which is more than $95 \%$ Christian, churches can contribute to public policy in PNG, enhance government transparency and account-ability, support social justice and peace building, and develop social capital. In addition, the churches in PNG play a crucial role in service delivery-some $50 \%$ of health services and $40 \%$ of the schools in PNG are run by the churches. In the context of PNG, where the government is relatively fragile with very little capacity, the role of the churches is especially important. The churches them-selves have strengths in their legitimacy, widespread presence, and ability to shape social capital but can benefit from stronger structures, systems, and development practice. Such capacity development is the highly relevant focus of the CPP. ${ }^{11}$

Many of the same considerations apply in the humanitarian sector, especially in work that is focussed on building community resilience, disaster risk reduction, and emergency response planning.
More broadly, there is a growing recognition of the particular value that faith-based organisations can bring to the humanitarian sector. $^{12}$ Multilateral agencies, including those attached to the UN, have in recent years specifically affirmed the contribution of faithbased actors. In 2013, the United Nations High Commissioner for Refugees (UNHCR) published a document, Welcoming the Stranger, drawing on affirmations of various faith leaders and religions setting out important humanitarian principles. ${ }^{13}$ In 2014, the UN Development Program published the formal Guidelines for Engaging with Faith-based Organisations and Religious Leaders. ${ }^{14}$ Similarly, the UNHCR has now published a practice note providing guidance on partnering with faith-based organisations in the humanitarian sector. ${ }^{15}$

This is highly relevant because there has been a historic reluctance for secular organisations and governments to engage with faith-based organisations. ${ }^{16}$ That position has changed and changed relatively quickly. The CAN DO consortium is one of a number of consortia and other organisations seeking funding from the Australian Government under its humanitarian partnerships program.

A related and equally important trend is the movement towards localisation in humanitarian practice. This refers to a greater commitment to local in-country organisations, especially grassroot organisations, being involved in the design and implementation of humanitarian programs. The trend towards localisation was championed at the 2016 World Humanitarian Summit. ${ }^{17}$ It acknowledged that local actors knew their context the best and had an essential role in designing and embedding initiatives affecting their own communities. Global commitments were made to fund and capacitate this important devolution of power.

\section{Establishing CAN DO}

These brief reflections indicate that the time was right for a consortium like CAN DO to take shape. With climate change posing as a major regional social challenge, there was an existing set of relationships that could be effectively leveraged, 
notably in the context of a more enlightened approach to funding faith-based consortia by government. While the last point is a welcome development, it should be noted that the CAN DO consortium was established with a commitment by members to use their own funds. That an additional source of funding is now in prospect is felicitous because it will allow added scale, but it was not a factor in establishing the consortium.

That said, it is a significant achievement that CAN DO has formed because there has never been a programmatic collaboration on this scale by Australian church-based development agencies. Presently there are eight participating organisations. They are Act for Peace, Adventist Development and Relief Agency, Anglican Board of Mission, Anglican Overseas Aid, Australian Lutheran World Service, Caritas Australia, Transform Aid International (Baptist World Aid), and UnitingWorld (Uniting Church). It should be noted that not every church denomination in Australia has its own aid and development organisation. Some churches choose to support the work of CAN DO member Act for Peace, which is the development arm of the National Council of Churches in Australia. In this way they are represented through CAN DO. Reaching an agreement with these many actors, each of differing sizes and capacities, for an undertaking that is both complex and ambitious is of itself noteworthy, so is the breadth of theological traditions represented within the group. This raises some interesting questions about how consortia are formed at the level of organisational theory.

One important factor in establishing CAN DO was capitalising on the strong sense of collegiality that existed between the various participating agencies, all of which were members of the Church Agencies Network in Australia (a group of international development organisations affiliated with churches or church bodies). That sense of collegiality stemmed from a shared sense of identity as Christian faith-based NGOs and was made explicit in the CAN DO Memorandum of Understanding that stated as its first guiding principle, "Faith matters. CAN DO and its partners are guided by Christian values and identity." 18
Shared Christian identity appears to be the basis of trust between the CAN DO members. Several published case studies have indicated the importance of common identity or faith in network development. ${ }^{19,20}$ In Uttarakhand, North India, one of the authors analysed the genesis of a network between faith-based health and develop-ment organisations. $^{19}$ A "broadly similar faith understanding" was identified as being the most significant factor determining the "ties" that bound members in the network. Such findings are consistent with social network theory that identifies homophily, or the tendency of individuals to associate and bond with similar "nodes", as important in facilitating network development. ${ }^{21-24}$ Homophily is often associated with strong interpersonal relationships and a strong sense of trust.

On the basis of their common faith, the CEOs of CAN DO members have been meeting together regularly for over a decade. In more recent years, staff representatives from each agency have formed practice groups for the purpose of sharing knowledge in specialist areas, including programming and humanitarian response. These kinds of interactions have helped develop a shared history and mutual respect. The salient point is that collaborations, like CAN DO, do not come out of a vacuum. A long-term structure has been in place to facilitate the cooperation that is now bearing fruit.

In addition to the programmatic foundations for CAN DO discussed above, the participants have realised that there is a range of other advantages from working in collaboration. These advantages are reflected in literature that describes how networks can increase effective-ness, capacity, and reach, and ultimately give rise to responses to wicked (complex and interdisciplinary) public health problems. ${ }^{19,21}$

For example, one factor in motivating the network formation was the desire to achieve programmatic coverage of as many Pacific island communities as possible. The presence and spread of denominations across different parts of the Pacific tend to reflect historic patterns of missionary activity. The breadth of the CAN DO 
consortium means that most areas of the Pacific are touched by one church partner or another.

It is also important in disaster preparedness that key messages are reiterated and understood as broadly as possible. This is especially the case in disseminating information about disaster risk reduction and in planning for emergencies. When key messages are socialised beyond one's coreligionists, this provides a helpful consistency and a useful reinforcement. This is a good example of how a network approach can be used to tackle an important social challenge.

Collaboration creates the capacity to produce resources suitable for use across all churches. CAN DO partners will have a central role in developing these resources, with the goal of building a sense of ownership and enhancing their ultimate utilisation. It has been observed that

... the language of faith, the religious idiom, frequently better reflects the cultural norms in which the poor and marginalised operate. They are better able to draw such individuals and communities into global discourse of social justice, rights and development, without recourse to the often distancing language of secular development discourse. ${ }^{25}$

Given the faith-infused nature of the Pacific society, this observation is especially apt. Also, given the similarities between the faith-based providers, this consortium is in a good position to facilitate the development and communication of appropriate messaging.

A final point is that, in theory, the network approach can keep costs for each participant to a minimum because each agency has committed to make its affiliated partner network available to the group. Thus, time and money are not wasted in replicating communication channels in-country (if that were in fact possible). The participants also have an appreciation of the possibilities made available to them by partnering together, including being able to engage multilateral agencies, national governments, and public and private funds. Various studies have highlighted such a benefit from networking. ${ }^{20,26}$

\section{Subtler Advantages}

In their discussions, CAN DO members have anticipated some advantages of a less tangible nature. One is the symbolic message about Christian unity projected by CAN DO to a range of stakeholders. CAN DO sees the group of agencies as proudly celebrating their overarching unity as Christian faith-based agencies by way of practical action while at the same time respecting their diverse traditions. This is a counterpoint to the sectarian tensions and suspicion that have sometimes existed between denominations at different points in Australia's church history.

They also note the possibility of building and strengthening forums for ecumenical co-operation among in-country church partners. Historically, there are some clear examples of ecumenical cooperation for the sake of the public good between Pacific churches. One is the role of churches in response to the civil conflict in the Solomon Islands from 1999 to 2003. During and after this period, "It was the churches [that] provided space for brokering peace and facilitating ongoing dialogue between different ethnic groups." ${ }^{27}$ It has been reported that undoubtedly, "Had the churches split along denominational lines, the conflict would have been far worse." 27 More recently, the Solomon Islands Christian Association has committed to developing a theology of gender to help combat high levels of domestic violence. These types of examples provide a high level of confidence about church cooperation to combat climate change and prepare for disasters.

\section{Risks and Concerns}

CAN DO is in its infancy, and it is acknowledged that much could go wrong. The picture painted is sanguine, reflecting initial enthusiasm for the task ahead. Careful management of several issues will be necessary to ensure that the program of work, and organisational relationships, stay on track.

One issue is the complexity of the consortium structure, with a relatively large number of direct participants and a layer of in-country partners also engaged in program development and delivery. 
Larger consortia are notoriously fragile, often because a sustainable balance cannot be achieved between the objectives of the consortium as a whole and the member's or partner's own interests. ${ }^{28} \mathrm{~A}$ transparent and objective decisionmaking process is essential along with an efficient conflict-resolution process.

Another complicating feature of CAN DO is the different capacities that exist within its membership. Some organisations are much larger and better resourced with a depth of specialist experience. Others are smaller but are anxious to learn through the process of collaboration itself. Whilst this has significant potential to build the capacity of smaller players, it raises the issue of how respective contributions of participants will be valued whilst maintaining program quality throughout.

At the outset, there is a clear and shared understanding that the work being undertaken is part of God's mission. It is hoped that the spirit of goodwill this imbues will enable the consortium to succeed in the longer term.

It is important that the actual results of the consortium are monitored over the coming years, so that the lessons learned can be shared. It is proposed to provide a report back when there is a sufficient body of field work and experience that can be meaningfully analysed.

\section{Concluding Reflections}

It is a significant achievement to get eight church-based development organisations, representing a diverse range of denominations, together for a programmatic collaboration of this kind. While caution is required, there is real cause for optimism. At one level, CAN DO was negotiated relatively quickly, over a few short months beginning late in 2015. Viewed in another light, however, CAN DO has had a gestation lasting over ten years.

As it begins its life, the potential benefits from this collaboration are significant. The consequence of climate change is a pressing concern throughout the Pacific, and a compelling case exists for responding through the churches. However, as this consortium unfolds, it is hoped that CAN DO will provide an inspiration and direction in other contexts.

A final thought is that CAN DO reminds church agencies of their tendency to sometimes pay too much attention to orthodoxy rather than orthopraxy in its broader sense. While by no means wanting to discount the importance of orthodoxy, when attention falls exclusively on questions of correct doctrine this can lead to unhelpful divisions, defensiveness and disunity. This makes collaborative actions much harder. Orthopraxy, on the other hand, refers to Christian practice, including how Christian faith should be expressed in practice and action. A unity based on orthopraxy is easier to achieve. There is little disagreement about God's call to reach out and serve the world as a vital expression of Christian faith. Opportunities to collaborate in the exercise of justice, compassion, and solidarity abound, and debates about doctrine need not stifle the common commitment to God's mission in the world. ${ }^{29}$

\section{References}

1. The International Fund for Agriculture Development. Climate Change Impacts - Pacfic Islands. 2011

2. Locke J. Climate change-induced migration in the Pacific region: Sudden crisis and long-term developments'. The Geographical Journal. 2009;175 (3):171-80. https://doi.org/10.1111/j.1475-4959.2008.00317.x

3. Seneviratne I, Nicholls, N., Easterling, D., Goodess, C., Kanae, S., Kossin, J., Luo, Y., Marengo, J., McInnes, K., Rahimi, M., Reichstein, M., Sorteberg, A., Vera, C., Zhang, X. Changes in climate extremes and their impacts on the natural physical environment. In: Field C, Barros, V., Stocker, T., Qin, D., Dokken, D., Ebi, K., Mastrandrea, M., Mach, K., Plattner, G., Allen, S., Tignor, M., Midgley, P., editor. A special report of working groups I and II of the Intergovernmental Panel on Climate Change. Cambridge and New York: Cambridge University Press; 2015. p. 109230.

https://doi.org/10.1017/CBO9781139177245.006

4. World Health Organisation Western Pacific Region. Climate change heightens Pacific island countries' vulnerability, according to a new report by WHO. [Accessed 21 January 2017]; Available 
from:

http://www.wpro.who.int/mediacentre/releases/201 6/20160426/en/

5. McIver L, Kim, R., Woodward, A., Hales, S., Spickett, J., Katscherian, D., Hashizume, M., Honda, Y., Kim, H., Iddings, S., Naicker, I., Bambrick, H., McMichael, A., Ebi, K. . Health impacts of climate change in Pacific island countries: A regional assessment of vulnerabilities and adaptation priorities. Environmental Health Perspectives. 2015. https://doi.org/10.1289/ehp.1509756

6. Robbins J. 'Pacific islands religious communities' in Juergensmeyer M (ed.) The Oxford handbook of global religions Oxford. Oxford: Oxford University Press; 2006. https://doi.org/10.1093/oxfordhb/9780195137989. $\underline{003.0057}$

7. Clarke M. Introduction: Good and God development and mission' in Clarke M (ed.) Mission and development: God's work or good works. London: Continuum; 2012. https://doi.org/10.5040/9781472549129.ch-001

8. Laking R. State performance and capacity in the Pacific. Manila: Asian Development Bank; 2010.

9. Hauck V, Mandie-Filer, A., Bolger, J. Ringing the church bell: The role of churches in governance and public performance in Papua New Guinea. Maastricht: European Centre for Development Policy Management 2005

10. Clarke M. Christianity and the shaping of Vanuatu's social and political developments. Journal for the Academic Study of Religion. 2015;28(1). https://doi.org/10.1558/jasr.v28i1.25723

11. Dart J, and Hall, J. Church Partnership Program, Papua New Guinea (case study report). Canberra: AusAid, September 2010

12.Duff J, Battcock, M., Karam, A., Taylor, A. Highlevel collaboration between the public sector and religious and faith-based organizations: Fad or trend? The Review of Faith \& International Affairs. 2016;14(3):95-100

13. United Nations High Commission on Refugees. Welcoming the Stranger: Affirmations for Faith Leaders. [16 January 2017]; Available from: http://www.unhcr.org/enau/protection/hcdialogue \%20/51b6de419/welcomi ng-stranger-affirmations-faith-leaders.html

14. United Nations Development Programme. UNDP Guidelines on Engaging with Faith-based Organizations and Religious Leaders. 2014
15. United Nations High Commission for Refugees. Partnership Note: On faith-based organisations, local faith communities, and faith leaders. Geneva: 2014

16. Grills N. The paradox of multilateral organizations engaging with faith-based organizations. Global Governance. 2009;15:505-20

17. United Nations General Assembly. Outcome of the World Humanitarian Summit Report of the Secretary-General. 2016

18. Memorandum of Understanding between CAN DO members. 2016; Available from:

http://churchagenciesnetwork.org.au/assets/docum ents/CAN-DO-Memorandum-of-

Understanding.pdf

19. Grills N, Robinson, P., \& Phillip, M. Networking between community health programs: a case study outlining the effectiveness, barriers and enablers. BMC Health Services 2012;12(206):1-12. https://doi.org/10.1186/1472-6963-12-206

20. Grills N, Kumar, R., Maneesh, P., \& Porter, G. . Networking between community health programs: A team-work approach to improving health service provision. BMC Health Services. 2014;14(297). https://doi.org/10.1186/1472-6963-14-297

21. Krueathep W, Riccucci, M., and Suwanmala, C. Why do agencies work together? The determinants of network formation at the subnational level of government in Thailand. Journal Public Administration Research and Theory. 2008;20:157-85. https://doi.org/10.1093/jopart/mun013

22. Agranoff R, and McGuire, M. Collaborative public management: new strategies for local governments. Washington D C: Georgetown University Press; 2003.

23. Scott J. The SAGE Handbook of Social Network Analysis. London: Sage; 2014. https://doi.org/10.4135/9781446294413

24. Lewis J. Connecting and cooperating: social capital and public policy. Sydney: UNSW press; 2010.

25. Clarke G, and Jennings, M. Development, civil society and faith-based organizations: Bridging the sacred and the secular. Bassingstoke: Macmillan 2008.https:/doi.org/10.1057/9780230371262

26. Kendall E, Muenchberger, H., Sunderland, N., Harris, M., Cowan, D. Collaborative capacity building in complex community-based health partnerships: a model for translating knowledge into action. Journal of Public Health Management 
and Practice. 2012;18(5):1-13.

https://doi.org/10.1097/PHH.0b013e31823a815c

27. Clarke M. "God I givim ples ya long yumi" (God has given us this land): the role of the church in building Pacific nations' in Mission and development: God's work or good works. London: Continuun; 2012. https://doi.org/10.5040/9781472549129.ch-005
28. Kreuter M, Lezin NA., Young, LA. Evaluating community-based collaborative mechanisms: implications for practitioners. Health Promot Practice. 2000;1(1):49-63. https://doi.org/10.1177/152483990000100109

29. Mitchell B. Faith-based development. New York: Orbis Books (USA); 2017

Peer Reviewed

Competing Interests: None declared.

Correspondence: Robert Bradley Mitchell, bmitchell@anglicanoverseasaid.org.au

Cite this article as: Mitchell R B, Grills N J. A historic humanitarian collaboration in the Pacific context. Christian Journal for Global Health. July 2017; 4(2):87-94. https://doi.org/10.15566/cigh.v4i2.160

(C) Mitchell R B, Grills N J This is an open-access article distributed under the terms of the Creative Commons Attribution License, which permits unrestricted use, distribution, and reproduction in any medium, provided the original author and source are properly cited. To view a copy of the license, visit https://creativecommons.org/licenses/by/4.0/

www.cjgh.org 